\title{
Analysis of Theory of Planned Behavior in Predicting Accountants' Interest in Gaining Chartered Accountant Titles in the Central Java Region
}

\author{
Dwi Artati \\ Department of Management \\ STIE Putra Bangsa \\ Kebumen Indonesia \\ dwiartati1709@gmail.com
}

\author{
Eni Kaharti \\ Department of Management \\ STIE Putra Bangsa \\ Kebumen, Indonesia \\ enikarahajeng198.stiepb@gmail.com
}

\author{
Ika Susilowati \\ Dapartement of Management \\ STIE Putra Bangsa \\ Kebumen, Indonesia \\ Hibahalili05@gmail.com
}

\begin{abstract}
The purpose of this study was to determine the interest of accountants in obtaining the title of Accountant. Through the application of planned behavior theory (TPB), this research is based on empirical evidence about the influence of perceptions and attitudes, subjective norms, and control of accountants' perceived behavior on the interest in obtaining the title of Accountant. The example used is students who are currently studying accountants in Central Java. In this study, all oxf the variables tested had passed the classical assumptions and validity and reliability before testing the hypothesis using the regression test with the SPSS 23 analysis tool. Where the results of this study found that the attitude variable (X1) had no effect on behavior intention, the subjective norm variable (X2) has no effect on behavioral intention, variable Perceived Behavioral Control (X3) affects behavior intention in obtaining the title Charter Accountant in Central Java.
\end{abstract}

Keywords: Theory Planned of Behavior, Charter Accountant, Attitude, Normal Subjective, Perceived Behavioral Control

\section{INTRODUCTION}

Towards entering the era of the ASEAN Economic Community (AEC) in 2015, Indonesia is one of the countries that competed in it. In the era of entering the Economic Community (AEC), labor resources in ASEAN countries can enter the ASEAN region with no exception. Especially for workers who have expertise and have international professional professions. As is the case for the accounting profession.

ACCA stands for Association of Chartered Certification Accountants, founded in 1904, is a global association for professional accountants. ACCA currently has 162 thousand members and 428 thousand students in 173 countries. ACCA has 91 offices around the world and collaborates with more than 8,500 companies that are recognized worldwide (Swa.co.id). Considering the importance of having an international professional certificate in competing to enter the free market area, it will require accountants who have the expertise shown by having this professional certificate, namely the Charter Accountant certificate. Having a Charter Accountant certificate has the opportunity to work at home and abroad because accountants with international certificates have a good prospect in the ASEAN Region.
Considering that the number of certified accountants is still small in the regions of ASEAN countries compared to the total population and the need for accountants in each country, it is necessary to re-examine their intentions for Charter Accountants. Theory of Planned Behavior (TPB) is an intention-based model developed by Ajzen [2]. This theory is a theory used to explain a person's intention to perform certain behaviors. By using this theory, the relationship between attitude towards chartered accountant and students' intention to have a career in chartered accountant will be examined again.

\section{LITERATURE REVIEW}

\section{A. Theory of Planned Behavior}

The theory of planned behavior (TPB) is a further development of the theory of reasoned action (TRA) [2]. Theory of Reasoned Action (TRA) describes behavior that changes based on the results of behavioral intention, and behavioral intention is influenced by social norms and individual attitudes toward behavior [9]. Theory of reason action developed by Ajzen and Fishbein, states that the best predictions about a person's behavior are based on that person's interests. Behavioral interest is based on 2 main factors, namely: individual belief in the results of the behavior carried out and individual perceptions of the views of the people closest to the individual on the behavior carried out.

TRA was developed into Theory of planned Behavior (TPB) by adding perceived behavioral control as a determinant of one's intention. Theory of Planned Behavior (TPB) overcomes the inaccuracies in Theory of Reasoned Action through research conducted by Fishbein and Ajzen. Theory of Planned Behavior (TPB) explains that a person's behavior is not only controlled by himself, but also controls the availability of certain resources and opportunities (perceived behavioral control) [4].

Perceived behavioral control is a construct variable that is added in an effort to complement the limitations that individuals have in carrying out a behavior. Perceived behavioral control is a construct that is not yet in the Theory of Planned Behavior (TPB). So in this Theory of Reasoned Action, the individual's perception of the control that can be exercised, which is rooted in the belief in the control, also determines whether or not a behavior is implemented other 
than being determined by subjective attitudes and norms. Ajzen concluded that TRA only applies to behavior that is under the full control of the individual, but it is not appropriate to explain behavior that is not completely under individual control, because there are factors that inhibit or facilitate the realization of intentions into behavior. Whereas previously there were many studies in the social sector that had proven that TRA was a theory that was sufficient in predicting behavior.

Planned behavior theory states that there are three main predictors that influence intention, namely attitude toward the behavior, subjective norms, and perceived behavioral control. Where is the description of the individual's intention to predict an individual's behavior.

\section{B. Attitude toward Behavior}

Attitude is a form of evaluation or feeling reaction. A person's attitude towards an object is a feeling of support or partiality. (favorable) and feelings of not supporting or not taking sides (unfavorable) on these objects [17]. Attitude towards behavior is the perception of an individual who believes that when he performs a behavior, a positive or negative feeling will appear which will influence him to behave (mihartinah

$\mathrm{H}_{1}$ : Attitude has a positive effect CA intention

\section{Subjective Norms}

Subjective norms are the second determinant basis of intention in the theory of planned behavior, subjective norms are still related to belief (beliefs), but belief in subjective norms is different from belief in attitude because belief in subjective norms is a perceptual representation of significant others (role models) either individually or in groups who then influence individuals whether to display behavior or not. Normative belief is a perception of behavior that is influenced by important people around individuals such as family, friends, or depending on the size of the population and the type of research taken [20].

$\mathrm{H}_{2}$ : Subjective Norms has a positive effect CA intention

\section{Perceived Behavior Control}

Perceived Behavioral Control has two effects, namely the influence on behavior intention and on behavior. PBC influences directly or indirectly (through intention) on behavior [4]. PBC is the belief that an individual has or has never carried out a certain behavior, the individual has the facilities and time to carry out the behavior, then the individual estimates his / her ability whether or not he has the ability to do that behavior. Ajzen named this condition perceived behavioral control. behavior control has a positive effect on career interests of PPAk students to become public accountants. This shows that the higher the behavior control they have someone, then from him a student will be interested in a career public accountant.[13]

H3: Perceived behavior control has a positive effect on tax payment intentions

\section{Chartered Accountant}

Chartered Accountant is an internationally certified accountant where this accountant becomes a professional accountant with recognized expertise and competence, and is also registered as a state-registered accountant. A state register of accountants is a list with the number and name of a person who has the right to use an Accounting degree as stated in the Regulation of the Minister of Finance of the Republic of Indonesia Number 25 / Pmk.01 / 2014 concerning State Registered Accountants Article 4 paragraph 2 states: "... can take the certification exam A professional accountant, a person must meet one of the following requirements: a) Have at least four diploma (D-IV) or bachelor's degree (S-1) in accounting organized by Indonesian or foreign universities that have been equivalent authorized in accordance with the provisions of laws and regulations in the field of education; b) Has a master's degree (S-2) or doctoral (S-3) education which emphasizes the application of accounting practices from Indonesian universities or foreign universities that have been equated by the competent authority in accordance with the provisions of laws and regulations in the field of education ; c) Attending accounting profession education; or d) Hold a level 6 (six) accounting technician certificate based on the Indonesian national qualification framework in accordance with the provisions of laws and regulations".

Chartered Accountant certification can be obtained through examinations provided by the authorized association. The exam will cover seven subjects according to the provisions. Exam participants who pass all courses will be required to practice for two or three years and participate in Continuing Professional Education (PPL) activities of at least 120 PPL Credit Units (SKP) to improve their competencies.

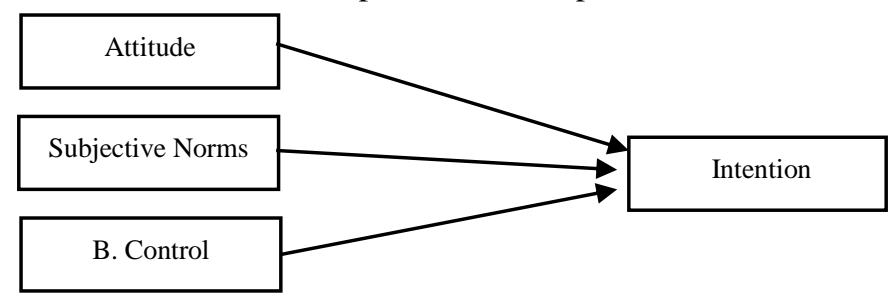

Fig 1. Research Model

\section{RESEARCH MODEL}

A. Sample and Population

The population in this study were prospective accountants who were currently studying the accounting profession in Central Java.

B. Data Collection Method

Primary data collection using a structured questionnaire given to research respondents. Respondents will rate each question using a 5-point Likert scale. (1) Strongly Agree (2) Agree (3) Neutral (4) Disagree (5) Strongly Disagree. Secondary data collection using the documentation method, namely finding and collecting materials in the form of books, journals and references related to research.

C. Data Analysis Technique

The hypothesis in this study was tested using multiple linear regression version with SPSS 23 analysis tool.

\section{A. Test Research Instruments}

\section{RESULT AND DISCUSSION}

\section{Validity Test}

The validity test can be done by comparing the calculated $r$ value with the $r$ table for degree of freedom $(d f)=n-2$. If $r$ count is greater than $r$ table and is positive then the question or indicator is declared valid. The number of samples processed (n) in this study were 56 respondents and the amount of df can 
be calculated to be $56-2=54$ with df 54 and alpha 0.05 , the $\mathrm{r}$ table is 0.2632 .

Table of Validity Test Results for Attitude Variables Variable Item $r$ count $r$ table significance

a. Variabel Attitude (X1)

Table I. Table of Validity Test Results for Attitude Variables

\begin{tabular}{cccccc}
\hline Variabel & Item & rhitung & r tabel & signifikansi & In \\
\hline \multirow{4}{*}{ Attitude } & X11 & 0,726 & 0,2632 & 0,000 & Valid \\
(X1) & X12 & 0,742 & 0,2632 & 0,000 & Valid \\
& X13 & 0,556 & 0,2632 & 0,000 & Valid \\
& X14 & 0,535 & 0,2632 & 0,000 & Valid \\
& X15 & 0,644 & 0,2632 & 0,000 & Valid \\
\hline
\end{tabular}

Source: processed data, 2020

The table above shows that the calculated $\mathrm{r}$ value is greater than $r$ table 0.2632 , with a significance value of $0.000<0.05$, so it can be concluded that all the attitude variable question instruments (X1) in the questionnaire are declared valid.

b. Variabel Subjective Norm (X2)

Table II. Table of Subjective Norm Validity Test Results

\begin{tabular}{cccccc}
\hline Variabel & Item & $\begin{array}{c}\mathrm{r} \\
\text { hitung }\end{array}$ & $\mathrm{r}$ tabel & signifikansi & In \\
\hline Subjective & $\mathrm{X} 21$ & 0,761 & 0,2632 & 0,000 & Valid \\
Norm & X22 & 0,463 & 0,2632 & 0,000 & Valid \\
(X2) & X23 & 0,743 & 0,2632 & 0,000 & Valid \\
& X24 & 0,568 & 0,2632 & 0,000 & Valid \\
& X25 & 0,612 & 0,2632 & 0,000 & Valid \\
\hline
\end{tabular}

Source: processed data, 2020

The table above shows that the calculated $\mathrm{r}$ value is greater than $r$ table 0.2632 , with a significance value of $0.000<0.05$, so it can be concluded that all questions on the variable Perceived Behavioral Control (X3) in the questionnaire are declared valid.

c. Variabel Perceived Behavioral Control (X3)

Table III. Table of Validity Test Results for Perceived Behavioral Control Variables

\begin{tabular}{cccccc}
\hline Variabel & Item & $\begin{array}{c}\mathrm{r} \\
\text { hitung }\end{array}$ & r tabel & signifikansi & In \\
\hline Perceived & X31 & 0,834 & 0,2632 & 0,000 & Valid \\
Behavioral & X32 & 0,870 & 0,2632 & 0,000 & Valid \\
Control & X33 & 0,854 & 0,2632 & 0,000 & Valid \\
(X3) & X34 & 0,690 & 0,2632 & 0,000 & Valid \\
\hline
\end{tabular}

Source: processed data, 2020

d. Variabel Behavioral Intention (Y)

Table IV. Table of Validity Test Results for Behavioral Intention Variables

\begin{tabular}{cccccc}
\hline Variabel & Item & $\begin{array}{c}\mathrm{r} \\
\text { hitung }\end{array}$ & r tabel & signifikansi & In \\
\hline Behavioral & YI & 0,746 & 0,2632 & 0,000 & Valid \\
Intention & Y2 & 0,854 & 0,2632 & 0,000 & Valid \\
(Y) & Y3 & 0,814 & 0,2632 & 0,000 & Valid \\
\hline
\end{tabular}

Source: processed data, 2020

The table above shows that the calculated $\mathrm{r}$ value is greater than $r$ table 0.2632 , with a significance value of $0.000<0.05$, so it can be concluded that all of the questions on the
Behavioral Intention $(\mathrm{Y})$ variable in the questionnaire are declared valid.

\section{Reliability Test}

A construct or variable is said to be reliable if it gives a Cronbach's Alpha value> 0.60 (Nunnally, 1960 in Ghozali, 2006). The results of the reliability of the questionnaire on each research variable are as follows:

Tabel V.Table of Research Instrument Reliability Test Results

\begin{tabular}{cccc}
\hline Variabel & $\begin{array}{c}\text { Cronbach's } \\
\text { Alpha }\end{array}$ & Criteria & In \\
\hline Attitude (X1) & 0,646 & 0,60 & Reliabel \\
$\begin{array}{c}\text { Subjective Norm } \\
\text { (X2) }\end{array}$ & 0,618 & 0,60 & Reliabel \\
PBC (X3) & 0,829 & 0,60 & Reliabel \\
$\begin{array}{c}\text { Behavioral Intention } \\
\text { (Y) }\end{array}$ & 0,728 & 0,60 & Reliabel \\
\hline
\end{tabular}

Source: processed data, 2020

Based on the table above, it can be shown that the value of the variable attitude, subjective norm, perceived behavioral control, behavioral intention is greater than 0.60 so that it can be declared reliable. This proves that the instrument from the questionnaire used to explain the variables attitude, subjective norm, perceived behavioral control, behavioral intention is declared reliable or can be trusted as a variable measuring tool.

\section{B. Classic Assumption Test}

In this test, the tested variables have passed the classical assumption test

\section{Hypothesis Test Results}

1. Multiple Linear Regression Analysis

Multiple Linear Regression Analysis Test Table

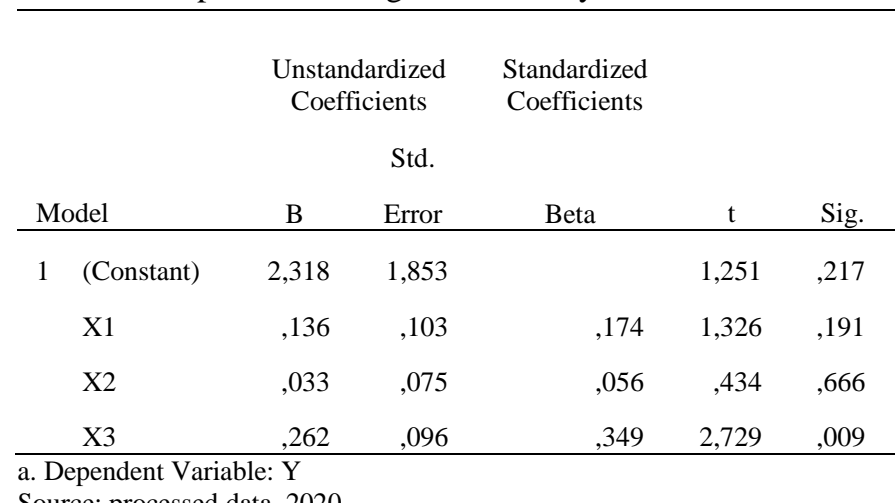

Source: processed data, 2020

To determine the effect between attitude (X1), Subjective norm (X2), Perceived Behavioral Control (X3), on Behavioral Intention (Y), it was carried out using the following regression equation:

Behavioral Intention $=2,318+0,136 \mathrm{X} 1+0,033 \mathrm{X} 2+0,262$

$\mathrm{X} 3+\mathrm{e}$

a: The constant (a) of 2.318 means that if the attitude, Subjective norm, Perceived Behavioral Control has a constant value at zero, then Behavioral Intention has a value of 2.318 . b1: The regression coefficient for $\mathrm{X} 1$ is 0.136 , meaning that every 1 unit addition to the attitude variable (X1) will increase 
the Behavioral Intention (Y) by 0.136 units, if other independent variables have a fixed value.

b2: The regression coefficient for $\mathrm{X} 2$ is 0.033 , meaning that every 1 unit addition to the Subjective norm (X2) variable will increase Behavioral Intention $(\mathrm{Y})$ by 0.033 units, if other independent variables have a fixed value.

b3: The regression coefficient for $\mathrm{X} 3$ is 0.262 , meaning that every 1 unit addition to the Perceived Behavioral Control (X3) variable will increase Behavioral Intention $(\mathrm{Y})$ by 0.262 units, if other independent variables have a fixed value.

e: The error value is 1.853 . This means that the error rate in the regression equation for the attitude variable, Subjective norm, Perceived Behavioral Control on Behavioral Intention is 1.853 .

2. Analysis of the coefficient of determination (R2) Determination Coefficient Test Output

\begin{tabular}{rrrrr}
\hline & & & Adjusted R & \multicolumn{2}{c}{$\begin{array}{c}\text { Std. Error of } \\
\text { the Estimate }\end{array}$} \\
\hline 1 & $\mathrm{R}$ & R Square & Square & thel \\
\hline &, $437^{\mathrm{a}}$ &, 191 &, 144 & 1,166 \\
\hline
\end{tabular}

a. Predictors: (Constant), X3, X2, X1

b. Dependent Variable: Y

Source: processed data, 2020

The table above shows the Adjusted R Square value of 0.144 . This indicates that the variable attitude, subjective norm, perceived behavioral control can only explain $14.4 \%$ of the variation of the Behavioral Intention variable. While the remaining $85.6 \%(100 \%-14.4 \%)$ is explained by other factors outside the model in this study.

3. Test Statistic t (Partial Test)

Table of Statistical Test Results t

\begin{tabular}{|c|c|c|c|c|c|}
\hline \multirow[b]{3}{*}{ Model } & \multicolumn{2}{|c|}{$\begin{array}{l}\text { Unstandardized } \\
\text { Coefficients }\end{array}$} & \multirow[t]{2}{*}{$\begin{array}{r}\text { Standardized } \\
\text { Coefficients }\end{array}$} & \multirow[b]{3}{*}{$\mathrm{T}$} & \multirow[b]{3}{*}{ Sig. } \\
\hline & & Std. & & & \\
\hline & B & Error & Beta & & \\
\hline $\begin{array}{ll}1 & \text { (Const } \\
& \text { ant) }\end{array}$ & 2,318 & 1,853 & & 1,251 & ,217 \\
\hline $\mathrm{X} 1$ & ,136 & ,103 & ,174 & 1,326 & ,191 \\
\hline $\mathrm{X} 2$ & ,033 & ,075 & ,056 & ,434 & ,666 \\
\hline $\mathrm{X} 3$ & ,262 & ,096 & ,349 & 2,729 & ,009 \\
\hline
\end{tabular}

a. Dependent Variable: Y

Source: processed data, 2020

a. Relationship between Attitude (X1) and Behavioral Intention (Y).

The $t$ test results in the table show that the significance value for the attitude variable (X1) is $0.191>0.05$ and the beta value is 0.136 is positive. The results of the calculation obtained the $\mathrm{t}$ count of $1.326<\mathrm{t}$ table of 2.00665 . So it can be concluded that the hypothesis is rejected, which means that the attitude variable (X1) has no effect on behavioral intention in obtaining the title Charter Accountant in Central Java.

b. Relationship between Subjective norm (X2) and Behavioral Intention (Y).
The $t$ test results in the table show that the significance value for the Subjective norm (X2) variable is $0.669>0.05$ and the beta value is 0.033 is positive. The results of the calculation obtained the $t$ count of $0.434<t$ table of 2.00665 . So it can be concluded that the hypothesis is rejected, which means that the subjective norm variable (X2) has no effect on behavioral intention in obtaining the title Charter Accountant in Central Java.

c. Relationship of Perceived Behavioral Control (X3) and Behavioral Intention (Y).

The $t$ test results in the table show that the significance value for the variable Perceived Behavioral Control (X3) is 0.009> 0.05 and the beta value of 0.262 is positive. The results of the calculation obtained the tcount of 2.729> t table of 2.00665 . So it can be concluded that the hypothesis is accepted, which means that the variable Perceived Behavioral Control (X3) affects behavioral intention in obtaining the title Charter Accountant in Central Java. This is in line with the findings of Dewi and Budiasih (2017), Islamylia and Mutia (2016), Solikhah (2014).

$$
\text { 4. F Test }
$$

Table of Statistical Test Results F

\begin{tabular}{|c|c|c|c|c|c|c|}
\hline \multicolumn{2}{|c|}{ Model } & $\begin{array}{l}\text { Sum of } \\
\text { Squares }\end{array}$ & Df & $\begin{array}{c}\text { Mean } \\
\text { Square }\end{array}$ & \multirow{2}{*}{$\frac{F}{4,091}$} & \multirow{2}{*}{$\frac{\text { Sig. }}{, 011^{\mathrm{b}}}$} \\
\hline 1 & Regression & 16,695 & 3 & 5,565 & & \\
\hline & Residual & 70,734 & 52 & 1,360 & & \\
\hline & Total & 87,429 & 55 & & & \\
\hline
\end{tabular}

Based on the table above, the results obtained from the $\mathrm{F}$ count is 4.091 and the F table value is $2.78(\mathrm{df} 1(\mathrm{~N} 1)=3$ and df2 $(\mathrm{N} 2)=56-3=53)$, this shows that the Fcount value is 4.091> Ftable of 2.78. While the significance value is 0.011 $<0.05$. Then the regression model can be used to predict behavioral intention or it can be said that the accepted hypothesis, namely attitude (X1), subjective norm (X2), and perceived behavioral control (X3) have a simultaneous effect on behavioral intention $(\mathrm{Y})$.

\section{CONCLUSION}

The attitude variable (X1) has no effect on behavioral intention in obtaining the title Charter Accountant in Central Java. This is in line with Mihatinah and Corynata's (2016) research that respondents do not have confidence that taking CA certification will give them positive things, in accordance with the results of hypothesis testing which states that attitudes towards behavior have no effect on the intention to take CA certification. For respondents, ownership of this certificate is also not a guarantee for their success and there is a view that this is just a waste of money. The same thing was also found by Bananuka et all (2019).

Subjective norm (X2) variable has no effect on behavioral intention in obtaining the title Charter Accountant in Central Java. This is the same as Sinaga's (2019) finding that 
subjective norms have no effect on behavioral intention. The same thing was also found by Ningsih and Zaky (2016). This indicates that pressure or encouragement from family, friends and colleagues cannot influence the intention to take a CA (Chartered Accountant) certificate.

The variable Perceived Behavioral Control (X3) affects behavioral intention in obtaining the title Chartered Accountant in Central Java. This means that student perceptions have a significant and positive effect on students to tend to choose to take the Chartered Accountant certificate. The results of this study are supported by previous research conducted by Gusti et.all (2013), and Sugahara, Hiramatsu and Boland (2009), Law, 2010; Solikah, 2014), namely that perception has an influence on intention.

It can be concluded that the respondents' interest in taking Chartered Accountants was not influenced by their perceptions of the merits of this predicate. It could also be that the respondent thinks that the existence of a Charter Accountant certificate is not sure that it will bring anything positive to them. So that the intention to have a Chartered Accountant certificate could be due to the demands and needs of work for accountant workers who are involved in the financial sector in this melenial era. Where accountants work is full of challenges so they need literature and information about Chartered Accountants.

\section{ACKNOWLEDGMENT}

This research is a research funded by the Ministry of Research and Technology of the Republic of Indonesia with the "Penelitian Dosen Pemula" scheme for 2019-2020.

\section{REFERENCES}

[1] Yusup, Al Haryono.1994. Accounting Basics. Volume 1. 4th Edition. Institute of Economic Science YKPN. Yogyakarta

[2] Ajzen I. (1991). The theory of planned behavior. Organizational Behavior and Human Decision Processes, 50(2): 179-211. doi: 10.1016/0749-5978(91)90020-T

[3] Ajzen, I., \& Fishbein, M., 1975, Belief, Attitude, Intention, and Behavior: An Introduction to Theory and Research, 129-385, AddisonWesley, Reading, MA.

[4] Ajzen, I., 1988, Attitudes, Personality, \& Behavior, Chicago: Dorsey Press.

[5] Anggraeni, Rahayu, 2013, Analysis of Theory of Panned Behavior in Predicting Tax Compliance of Central, Provincial and District Taxpayers, Thesis, Unsoed.

[6] Badingatus, Solikhah.2014."An application of theory of planned behavior towards CPA career in Indonesia. Procedia - Social and Procedia - Social and Behavioral Sciences 164 (2014) 397 - 402.

[7] Bananuka, J., Kasera, M., Najjemba, G. M., Musimenta, D., Ssekiziyivu, B., \& Kimuli, S. N. L. (2019). Attitude: mediator of subjective norm, religiosity and intention to adopt Islamic banking. Journal of Islamic Marketing.

[8] Dewi, N. K. D. K., \& Budiasih, I. G. A. N. (2017). The Influence of Emotional Intelligence, Subjective Norms, and Behavioral Control on Career Interests of Accounting Professional Education Students. Udayana University Accounting E-Journal, 20.

[9] Eagle, Lynne, Dahl, Stephen, Hill, Suzie, Bird, Sara, Spotswood, Fiona, and Tapp, Alan (2013) Social Marketing. Pearson Education, Edinburgh Gate.

[10] Felton et.al.1995. A Theory of Reasoned Action Model of the Chartered Accountant Career Choice. Journal of Accounting Education, Vol. 13, No. 1, pp. 1-19, 1995

[11] Fishbein, M. (1980). A theory of reasoned action: Some applications and implications. In M. M. Page (Ed.), Nebraska symposium on motivation (pp. 27).

[12] Ikatan Akuntan Indonesia (IAI). (2014) Prepare Yourself to Welcome the ASEAN Single Market ". Accessed through http://www.iaiglobal.or.id. On November 16, 2016, at 2:35 p.m..“

[13] Islamylia, I., \& Mutia, E. (2016, ). The Influence of Attitudes, Subjective Norms, Behavior Control, Spiritual Motivation on the Interest of Accounting Students in Choosing the Islamic Accountancy Concentration at the Faculty of Economics, Syiah Kuala University. Accounting Economics Student Scientific Journal 1(1), 192-203.

[14] Kotler, Philip and Kevin Lane Keller, 2011. Marketing Management 13th Edition Vols 1 and 2, Translation: Bob Sabran, Erlangga, Jakarta.

[15] Kwarto, F., \& Saputra, H. Factors Affecting Career Selection as a Professional Accountant Based on PMK no. 25 / pmk. 01/2014 in Dealing With Asean Economic Community (AEC) With Self-Efficacy as a Moderation Variables.

[16] Law, Philip K. 2010. “A Theory of Reasoned Action Model of Accounting Students' Career Choice in Public Accounting Practices in the Post-Enron". Journal of Applied Accounting Research, Vol 11, No. 1, h. 58-73

[17] Mustika,Elia, 2007, X Empirical Study of Corporate Taxpaye Compliance in Processing Industry Companies in Surabaya. Accounting National Symposium: 1-42

[18] Mihartinah, D., \& Coryanata, I. (2018)., The Influence of Attitudes on Behavior, Subjective Norms, and Perceived Behavior Control on the Intention of Accounting Students to Take Chartered Accountan Certification. Accounting journal 8(2), 77-88.

[19] Ningsih, I. S. P., \& Zaky, A. (2014). Determinants of Student Intention in Choosing a Concentration in Islamic Accounting and Finance. Student Scientific Journal FEB, 3(1)

[20] Puruhita, R., \& Zaky, A. (2014) Student Interest with a Natural Science Background in Choosing a Department of Accounting as a Lecture Major. Student Scientific Journal. FEB, 3(1).

[21] Raminten (2012) " The influence of motivation on the interest of accounting students to follow pendidikan profesi akuntansi (PPAk)" Juraksi vol.1 no.2. ISSN: 2301-9328

[22] Sugahara, Satoshi dan Boland, Gregory. (2006). "Perceptions of the Certified Public Accountants by Accounting and Non-accounting Tertiary Students in Japan". Asian Review of Accounting, Vol. 14, No. 1/2, h. 149-167.

[23] Wardani, G. A. S., \& Januarti, I. (2016) Intention to take chartere accountants with a theory of planned behavior (Doctoral dissertation, Faculty of Economics and Business.).

[24] www.iaiglobal.or.id

[25] http://Swa.co.id 